\title{
Strategi Pelestarian Mangrove Berbasis Ekowisata di Pantai Cemara Kabupaten Banyuwangi
}

\section{Ecotourism-Based Mangrove Conservation Strategy in Cemara Beach, Banyuwangi Regency}

\author{
Rudi Mulyanto ${ }^{1}$, Irwan Kurniawan Soetijono ${ }^{1}$, Marwiyah ${ }^{1,}$ Syafriza Akbar ${ }^{1}$, \\ Chyntabela Puspita Martha ${ }^{{ }^{*}}$ \\ ${ }^{1}$ Program Stsudi Hukum, Fakultas Hukum, Universitas 17 Agustus Banyuwangi, Jalan Adi Sucipto No. \\ 26, Banyuwangi, Jawa Timur, Indonesia. \\ Corresponding Author: irwankurniawan616@gmail.com
}

Submited: 22 June 2021 Revised: 05 July 2021 Accepted: 22 July 2021

Publish: 31 July 2021

\begin{abstract}
Abstrak
Pengelolaan hutan mangrove merupakan hal penting bagi upaya pelestarian lingkungan di kawasan pesisir. Tujuan penelitian ini untuk mengetahui kegiatan rehabilitasi hutan mangrove dan strategi pengeloloaan hutan mangrove secara lestari melalui ekowisata di Pantai Cemara Kabupaten Banyuwangi. Penelitian ini mempergunakan pendekatan survei serta wawancara langsung dan pengamatan lapangan. Dampak yang ditimbulkan dengan adanya rehabilitasi hutan mangrove di daerah penelitian adalah meningkatnya hasil tangkapan ikan, mengurangi abrasi pantai, menahan tiupan angin laut, serta semakin banyak jenis tangkapan biota baik berupa udang, kerang dan kepiting di sekitar mangrove. Dampak lain yang ditimbulkan adalah bertambahnya daya tarik pantai cemara sehingga layak dijadikan sebagai obyek wisata khususnya wisata berbasis ekologi. Adapun strategi yang perlu dilakukan dalam pengelolaan hutan mangrove antara lain adalah penanaman pohon mangrove, penguatan lembaga pengelola pantai, peningkatan Sumber Daya Manusia (SDM) kelompok nelayan, peningkatan kerja sama dengan stake holder, diversifikasi penghasilan perempuan nelayan Pantai Cemara dan inovasi atraksi wisata berbasis ekologi (ekowisata) di Pantai Cemara Kabupaten Banyuwangi.
\end{abstract}

Kata kunci: Ecotourism, Mangrove, Pantai Cemara, Strategi pelestarian

\section{Abstract}

Mangrove forest management is important for environmental conservation efforts in coastal areas. The purpose of this study was to determine the activities of mangrove forest rehabilitation and sustainable mangrove forest management strategies through ecotourism at Cemara Beach, Banyuwangi Regency. This study used a survey approach as well as direct interviews and field observations. The impact caused by the rehabilitation of mangrove forests in the study area is increasing fish catches, reducing coastal abrasion, resisting sea breezes, and increasing the number of types of biota catches in the form of shrimp, shellfish, and crabs around the mangroves. Another impact is the increase in the attractiveness of the fir beach so that it is worthy of being used as a tourist attraction, especially eco-based tourism. The strategies that need to be carried out in the management of mangrove forests include planting mangrove trees, strengthening coastal management institutions, increasing human resources (HR) for fishing groups, increasing collaboration with stakeholders, diversifying the income of women fishermen from Cemara Beach, and innovating eco-based tourist attractions. Ecotourism at Cemara Beach, Banyuwangi Regency. Keywords: Ecotourism, Mangrove, Cemara Beach, Conservation strategy.

\section{PENDAHULUAN}

PBB melalui forum UNCSGN

(United Nations Conference on

Standardization of Geographical

Names) menyelenggarakan konferensi ke-11th pada 7-18 Agustus 2017

bertempat di Markas Besar PBB New

York. Pada forum tersebut Badan

Informasi Geospasial (BIG) sebagai 
lembaga pemerintah nonkementerian yang bertugas melaksanakan tugas pemerintahan di bidang informasi geospasial telah berhasil melakukan verifikasi sebanyak 2.590 pulau bernama untuk dapat dilaporkan ke PBB. Sehingga saat ini diasumsikan di Indonesia terdapat 17.504 pulau, dan capaian di 2017 telah mencatatkan secara formal sejumlah 16.056 pulau bernama ke PBB, maka BIG masih menyisakan sebanyak 1.448 pulau belum bernama (Administrator 2018).

Berdasarkan Deklarasi Juanda tertanggal 13 Desember 1957, bahwa laut Indonesia yang terdiri dari laut sekitar, di antara dan di dalam kepulauan Indonesia menjadi satu kesatuan wilayan NKRI. United Nation Convention On The Law Of The Sea (UNCLOS) 1982 yang telah diratifikasi dengan Undang-undang No. 17 Tahun 1985 dinyatakan bahwa total luas laut Indonesia adalah 5,9 juta $\mathrm{km} 2$, terdiri atas 3,2 juta $\mathrm{km} 2$ pertairan teritorian dan $2,7 \quad \mathrm{~km} 2$ perairan zona ekonomi eksklusif (ZEE). Dan luas tersebut belum termasuk landasan kontinen (continent shelf). Kekayaan tersebut mengukuhkan indonesia sebagai negara kepulauan terbesar di dunia (the biggest archipelago in the world) (Safitri et al. 2020).

Indonesia dikenal sebagai salah satu negara yang memiliki keanekaragaman hayati tertinggi di dunia. Keanekaragaman hayati (biological diversity) adalah istilah yang dipergunakan untuk menerangkan keragaman ekosistem dan berbagai bentuk serta variabilitas hewan, tanaman, jasad renik di dunia. Dengan demikian keanekaragaman hayati mencakup keragaman ekosistem (habitat), jenis (spesies) dan genetik (varietas/ras).

Tingginya kekayaan sumber daya alam hayati indonesia dimungkinkan oleh beberapa faktor, yaitu (1) keseluruhan luas wilayah sekitar 8 juta kilometer persegi, di mana 1,9 juta kilometer berupa daratan, (2) keadaan geografis yang terdiri dari kepulauan terpisah dan saling berjauhan sehingga mendorong terjadinya spesiasi (pembentukan spesies), (3) terletak di antara dua wilayah biogeografi yaitu Indo Malaya di sebelah barat dan australia di sebelah timur, sehingga susunan flora dan faunanya merupakan gabungan dari flora dan fauna kedua 
wilayah tersebut, (5) tipe ekosistem yang beranekaragam mulai pantai hingga pegunungan bersalju diperkirakan mencapai 47 ekosistem (Soemarsono 1998).

Di samping jumlahnya yang besar, sumber daya alam yang dimiliki indonesia termasuk spesifik. Besar dalam arti kuantitas atau jumlahnya yang banyak dan spesifik dalam arti jenisnya yang khas, yaitu tidak terdapat di negara lain. Hal ini dapat diketahui dengan adanya kenyataan bahwa Indonesia yang hanya menempati $13 \%$ dari seluruh luas wilayah daratan dunia, memiliki $17 \%$ dari seluruh kekayaan hayati dan berbagai ekosistemnya yang sebagian di antaranya tidak dijumpai di belahan bumi manapun. Indonesia diperkirakan memiliki $11 \%$ dari spesies tumbuhan berbunga yang sudah diketahui, $12 \%$ binatang menyusui, $17 \%$ jenis burung, 37\% jenis ikan di dunia, 15\% amfibi dan reptilia di dunia terdapat di Indonesia (Sembiring 1999). Di antar kekayaan keanekaragaman hayati tersebut adalah mangrove.

Ekosistem mangrove merupakan ekosistem yang berada di daerah tepi pantai yang dipengaruhi oleh pasang surut air laut sehingga lantainya selalu tergenang air. Ekosistem mangrove berada di antara level pasang naik tertinggi sampai level di sekitar atau di atas permukaan laut rata-rata pada daerah pantai yang terlindungi (Supriharyono 2009), dan menjadi pendukung berbagai jasa ekosistem di sepanjang garis pantai di kawasan tropis.

Manfaat ekosistem mangrove secara ekologis adalah sebagai mitigasi bencana seperti peredam angin badai dan gelombang bagi daerah pesisir, pelindung pantai dari abrasi, gelombang air pasang (rob), tsunami, penahan lumpur dan perangkap sedimen yang diangkut oleh aliran air permukaan, pencegah intrusi air laut ke daratan, serta dapat menjadi penetralisir pencemaran perairan pada batas tertentu. Manfaat lain dari ekosistem mangrove ini adalah sebagai obyek daya tarik wisata alam dan atraksi ekowisata dan sebagai sumber tanaman obat. Ekosistem mangrove berfungsi pula sebagai habitat berbagai jenis satwa. Peran penting ekosistem mangrove bagi pengembangan perikanan pantai karena mangrove merupakan tempat memijah, berkembang biak, dan membesarkan 
anak bagi beberapa jenis ikan, kepiting, udang dan kerang. Jika dibandingkan dengan perairan terbuka jenis plankton lebih banyak terdapat di habitat mangrove. Perlindungan dan makanan berupa bahan organik ke dalam rantai makan banyak tersedia di hutan mangrove. Berbagai jenis hewan darat, seperti monyet, reptil, serangga, burung, dan kelelawar mempergunakan bagian kanopi mangrove sebagai tempat hidupnya (Supriharyono 2009). Kayu pohon mangrove dapat digunakan sebagai kayu bakar, bahan pembuatan arang kayu, bahan bagunan, dan bahan baku bubur kertas. Manfaat nilai guna langsung hutan mangrove sebesar Rp. $11,61 \mathrm{juta} / \mathrm{ha} / \mathrm{th}$.

\section{METODE PENELITIAN}

Metode penelitian dipergunakan dalam penelitian ini adalah metode kualitatif. Tujuannya adalah untuk mengetahui kebijakan pengelolaan pantai cemara terkait rehabilitasi hutan mangrove dan pemanfaatan habitat mangrove dibidang jasa lingkungan yakni ekowisata di kawasan pantai cemara banyuwangi.

\section{HASIL DAN PEMBAHASAN}

Menurut UNWTO, pariwisata diartikan sebagai tindakan wisata untuk tujuan rekreasi dan bisnis serta penyediaan sarana prasarana dan layanan untuk tindakan tersebut. Pariwisata dalam UU No 10 tahun 2009 tentang Kepariwisataan diartikan berbagai macam kegiatan wisata dan didukung berbagai fasilitas serta layanan yang disediakan oleh masyarakat, pengusaha, pemerintah dan pemerintah daerah. Sedang wisata diartikan sebagai kegiatan perjalanan yang dilakukan oleh seseorang atau sekelompok orang dengan mengunjungi tempat tertentu untuk tujuan rekreasi, pengembangan pribadi, atau mempelajari keunikan daya tarik wisata yang dikunjungi dalam jangka waktu sementara. Kepariwisataan merupakan bagian integral dari pembangunan nasional yang dilakukan secara sistematis, terencana, terpadu, berkelanjutan, dan bertanggung jawab dengan tetap memberikan perlindungan terhadap nilai-nilai agama, budaya yang hidup dalam masyarakat, kelestarian dan mutu lingkungan hidup, serta kepentingan nasional. Disisi lain, pembangunan kepariwisataan diperlukan untuk mendorong pemerataan kesempatan berusaha dan 
memperoleh manfaat serta mampu menghadapi tantangan perubahan kehidupan lokal, nasional, dan global. Kabupaten Banyuwangi sebagai daerah dengan luas lebih dari $5.000 \mathrm{~km}$ persegi memiliki berbagai potensi yang dapat dijadikan sebagai modal pembangunan pariwisata. Selain dikenal sebagai daerah dengan keragaman budaya, banyuwangi juga dikenal dengan kekayaan alam yang potensi bagi pengembangan pembangunan pariwisata. Terdapat gunung Raung dan Gunung Ijen yang terkenal dengan Kawah Ijen. Banyuwangi juga dikelilingi oleh keanekaramagan hayati di 3 (tiga) taman Nasional yakni taman nasional meru betiri, taman nasional alas purwo dan taman nasional baluran. Di bidang kelautan banyuwangi memiliki sekitas $180 \mathrm{~km}$ garis pantai yang amat potensial bagi bidang perikanan serta jasa lingkungan terutama pariwisata. Perkembangan isu global menghendaki pengelolaan wisata bukan lagi pada wisata massal (mass tourism ) akan tetapi beralih pada wisata berbasis ekologi atauecological tourism / ecotourism yang sering dialih bahasakan sebagai ekowisata.

Pengertian ekowisata sendiri menurut The International Ecotourism Society (TIES) adalah perjalanan wisata alam yang bertanggung jawab terhadap lingkungan dan meningkatkan kesejahteraan masyarakat lokal. Ekowisata berbasis masyarakat merupakan usaha ekowisata yang menitikberatkan peran aktif masyarakat karena masyarakatlah sebagai pemilik pengetahuan tentang alam serta budaya yang menjadi potensi dan nilai jual sebagai daya tarik wisata, sehingga pelibatan masyarakat menjadi mutlak. Pola ekowisata berbasis masyarakat mengakui hak masyarakat lokal dalam mengelola kegiatan wisata di kawasan yang mereka miliki secara adat ataupun sebagai pengelola. Dengan adanya pola ekowisata berbasis masyarakat bukan berarti masyarakat akan menjalankan usaha ekowisata sendiri. Berdasarkan Peraturan Menteri Dalam Negeri Nomor 33 Tahun 2009 tentang Pengembangan ekowisata di daerah menyatakan bahwa prinsip pengembangan ekowisata meliputi: (1) kesesuaian antara jenis dan karakteristik ekowisata;

konservasi, yaitu melindungi, mengawetkan, dan memanfaatkan 
secara lestari sumberdaya alam yang digunakan untuk ekowisata;

ekonomis, yaitu memberikan manfaat untuk masyarakat setempat dan menjadi penggerak pembangunan ekonomi di wilayahnya serta memastikan usaha ekowisata dapat berkelanjutan; (4) edukasi, yaitu mengandung unsur pendidikan untuk mengubah persepsi seseorang agar memiliki kepedulian, tanggung jawab, dan komitmen terhadap pelestarian lingkungan dan budaya; (5) memberikan kepuasan dan pengalaman kepada pengunjung; (6) partisipasi masyarakat, yaitu peran serta masyarakat dalam kegiatan perencanaan, pemanfaatan, dan pengendalian ekowisata dengan menghormati nilai- nilai sosialbudaya dan keagamaan masyarakat di sekitar kawasan; dan (7) menampung kearifan lokal. Dampak adalah suatu perubahan yang terjadi sebagai akibat suatu aktivitas.

Pariwisata merupakan salah satu sektor penting dalam pembangunan. Pengelolaan pariwisata yang baik akan menghasilkan beberapa keuntungan dalam berbagai aspek. Akan tetapi, apabila tidak dikelola dengan benar, maka pariwisata dapat berpotensi menimbulkan masalah atau dampak negatif. Beberapa dampak positif pariwisata antara lain (Hijriati and Mardiana 2014): 1. Menciptakan kesempatan kerja; 2. Menciptakan kesempatan berusaha; 3. Meningkatkan penerimaan pajak pemerintah dan retribusi daerah; 4. Meningkatkan pendapatan sekaligus mempercepat pemerataan pendapatan masyarakat, sebagai akibat multiplier effect yang terjadi dari pengeluaran wisatawan yang relatif cukup besar; 5. Mendorong peningkatan investasi dari sektor industri pariwisata dan sektor ekonomi lainnya; 6. Meningkatkan pendapatan nasional atau Gross Domestic Bruto (GDB

Selain dampak positif, pariwisata ternyata juga membawa dampak negatif. Bagi masyarakat lokal, industri pariwisata kadangkala tidak mengikutsertakan dalam pembangunan pariwisata, kadangkala menempatkan masyarakat lokal sebagai penonton pembangunan pariwisata. Peningkatan jumlah pengunjung/wisatawan tanpa memperhatikan daya dukung dan daya tampung lokasi wisata menyebabkan kerusakan baik bagi alam maupun budaya di tempat wisata. Pencemaran 
oleh sarana akomodasi, pengelolaan sampah secara serampangan merupakan dampak negatif lain dari industri wisata. Untuk itu diperlukan straregi yang komprehensif sehingga manfaat pembangunan pariwisata dapat secara optimal dirasakan oleh para pemangku kepentingan antara lain pengelolaan dengan melibatkan masyarakat lokal (pembangunan partisipatif), mengedepankan perencanaan dan pelaksanaan berdasarkan kaidah konservasi serta mengakomodasi budaya masyarakat lokal. Prinsip tersebut berupaya diterapkan secara maksimal dalam pengelolaan ekowisata mangrove di Pantai Cemara Banyuwangi.

Adapun strategi yang perlu dilakukan dalam pengelolaan hutan mangrove antara lain adalah penanaman pohon mangrove, penguatan lembaga pengelola pantai, peningkatan Sumber Daya Manusia (SDM) kelompok nelayan, peningkatan kerja sama dengan stake holder, diversifikasi penghasilan perempuan nelayan Pantai Cemara dan inovasi atraksi wisata berbasis ekologi (ecotourism) di Pantai Cemara Kabupaten Banyuwangi.

Ekosistem mangrove dipahami nelayan sebagai kawasan yang memiliki dampak positif bagi kelangsungan hidup sehari-hari. Pola penghidupan nelayan kecil dengan sumberdaya terbatas hanya mampu menjalankan pekerjaan yang bersifat pemenuhan kebutuhan sehari-hari. Kondisi tersebut membuat nelayan menyadari bahwa mangrove yang telah ada di Panti Cemara sejak jaman dahulu wajib dijaga kelestariannya. Nelayan menyadari bahwa nafkah hidup mereka bisa ditemukan pada kawasan mangrove. Ikan, kepiting, udang dan aneka kerang-kerangan bisa didapatkan dikawasan mangrove.

Upaya yang dilakukan oleh KUB Pantai Rejo adalah tetap menjaga kelestarian kawasan mangrove antara lain dengan tidak menebang secara sembarangan bahkan terus melakukan penanaman mangrove di Pantai Cemara terutama sekitar muara sungai. Pengetahuan tentang tanaman mangrove tentu tidak begitu saja didapatkan oleh nelayan pantai rejo. Proses belajar dari sesama nelayan dilakukan mulai dari nelayan di kecamatan Muncar hingga kecamatan Wongsorejo.

Nelayan Pantai Cemara juga memperoleh bimbingan dari beberapa 
dinas terkait yakni Dinas Perikanan dan Kelautan serta Dinas Pariwisata dan Kebudayaan Kabupaten Banyuwangi. Beragam program dan kegiatan yang dilaksanakan oleh dinas-dinas tersebut yang bertujuan meningkatkan kapasitas sumber daya manusia (sdm) nelayan. Dinas Kelautan dan Perikanan melakukan pendampingan pengelolaan mangrove secara lestari dan penanaman pohon cemara. Hingga saat ini telah tumbuh ribuan batang pohon cemara sehingga pantai cemara layak dijadikan sebagai hutan kota Banyuwangi sekaligus kawasan konservasi. Suasana alami turut mengundang hadirnya penyu ke pantai Cemara. Jenis penyu yang mendarat dan bertelur di pantai cemara antara lain adalah Penyu Hijau (Chelonia mydas) dan Penyu Lekang (lepidochely solivacea). Satwa penyu berada dalam daftar IUCN Red List of Threatened Species artinya kategori yang di gunakan IUCN terhadap spesies mahluk hidup yang terancam punah. IUCN (International Union for the Conservation of Nature and Natural Resources) merupakan organisasi yang beranggotakan pemerintah dari berbagai negara serta organisasi masyarakat sipil yang mengeluarkan daftar status kelangkaan suatu spesies.

Strategi lain yang dilakukan berkenaan dengan aktivitas wisatawan yang erat dengan kegiatan wisata berkelanjutan antara lain adalah menyusuri sungai di sepanjang hutan mangrove dengan atraksi aneka burung dan reptil. Nelayan pantai cemara juga bekerja sama dengan sekolah, lembaga sosial dan perusahaan swasta untuk melakukan penanaman pohon cemara yang bertujuan sebagai sarana edukasi dan sosialisasi konsep pariwisata yang berkelanjutan. Pemberdayaan perempuan nelayan dilakukan melalui pelatihan pemanfaatan mangrove sebagai makanan ringan sekaligus sirup mangrove. Kegiatan ini juga sebagai diversifikasi mata pencaharian bagi keluarga nelayan.

\section{KESIMPULAN}

Pantai Cemara Kabupaten Banyuwangi merupakan salah satu wilayah pesisir yang terletak tidak jauh dari pusat kota. Kedekatan ini bermanfaat bagi keberlangsungan pemenuhan kebutuhan masyarakat akan udara segar. Keberadaan Pantai Cemara sebagai area publik sekaligus hutan kota selain berfungsi sebagai 
sarana rekreasi juga sebagai wisata edukasi mengingat Pantai Cemara secara alami merupakan tempat penetasan penyu dan tempat habibat mangrove.

Strategi pelestarian mangrove di Pantai Cemara antara lain adalah dengan menggandeng kelompok nelayan yang selama ini menjadikan Pnatai cemara sebagai tempat mencari pemenuhan kebutuhan sehari-hari. Pengelolaan Pantai cemara olah KUB Pantai Rejo merupakan perwujudan pengelolaan potensi wisata berbasis masyarakat. Upaya pemberdayaan masyarakat KUB antara lain melalui kerja sama dan pendampingan kelompok nelayan baik dengan sesama kelompok nelayan, pendampingan oleh pemerintah melalui dinas kelautanan perikanan sertta dinas pariwisata kabupaten Banyuwangi. Pendampingan juga dilakukan oleh perguruan tinggi terutama pengenalan dan pendampingan pengelolaan hutan mangrove secara lestari dan pelatihan keterampilan ekonomi perempuan nelayan sebagai diversifikasi mata pencaharian nelayan.

\section{Ucapan Terima Kasih}

Ucapan terima kasih kami tujukan kepada Rektor Universitas 17 Agustus 1945 Banyuwangi, Dekan Fakultas Hukum Universitas 17 Agustus 1945 Banyuwangi, KUB Pantai Rejo dan pusat kajian anti korupsi dan perundang-undangan (PUSKAKOP) Universitas 17 Agustus 1945 Banyuwangi.

\section{DAFTAR PUSTAKA}

Administrator. 2018. "Pulau-Pulau Itu Punya Nama.” 2018.

https://indonesia.go.id/ragam/budaya/kebudayaa n/pulau-pulau-itu-punya-nama.

Hijriati, E., \& Mardiana, R. (2014). Pengaruh ekowisata berbasis masyarakat terhadap perubahan kondisi ekologi, sosial dan ekonomi di Kampung Batusuhunan, Sukabumi. Jurnal Sosiologi Pedesaan, 2(3): 146-159.

Safitri, M. A., Azis, A. P. A., Riverningtyas, S. I., Wibawa, I. P. S., Assidiq, H., Anwar, M., ... \& Mulyono, A. T. (2020). Covid-19, Perubahan Iklim dan Akses Rakyat terhadap Keadilan. Media Sains Indonesia.

Sembiring, Sulaiman N. 1999. Kajian Hukum Dan Kebijakan Pengelolaan Kawasan Konservasi Di Indonesia Menuju Pengembangan Desentralisasi Dan Peningkatan Peran Serta Masyarakat. Jakarta: ICEL.

Soemarsono. 1998. Konservasi Satwa Liar Sebagai Upaya Menjaga Ekosistem Dan Meningkatkan Kesejahteraan Manusia Di Era Perdagangan Bebas. Jakarta: Jenderal Perlindungan dan Pelestarian Alam, Departemen Kehutanan dan Perkebunan.

Supriharyono. 2009. Konservasi Ekosistem Sumberdaya Hayati Di Wilayah Pesisir Dan Laut Tropis. Yogyakarta: Pustaka Pelajar. 
Journal of Aquaculture Science

DOI: https://doi.org/10.31093/joas.v6i1IS.167
July 2021 Vol 6 Issue Spesial: 148-156

Online pada http://joas.co.id 